\title{
Physical Properties and Chemical Composition of the Rice Husk and Dust
}

\section{TATYANA GERMANOVNA KOROTKOVA, SVETLANA JUREVNA KSANDOPULO, ALEKSANDR PAVLOVICH DONENKO, SVYATOSLAV ANDREEVICH BUSHUMOV and ALEKSANDRA SERGEEVNA DANILCHENKO}

\author{
Kuban State Technological University, Russian Federation, 350072, Krasnodar, \\ Moskovskaya Street, 2.
}

http://dx.doi.org/10.13005/ojc/320644

(Received: November 03, 2016; Accepted: December 11, 2016)

\begin{abstract}
The paper deals with the physical properties and chemical composition of rice husk and dust, which are the waste of the Regulus raw rice growing in the Krasnodar Region of the Russian Federation. Rice dust is formed as a result of the discharge upon the receipt of raw rice from vehicles, removal of impurities, sorting by size, during separation of membranes, crushing, grinding, polishing, moving grain along the elevators and conveyors, i.e. during all technological operations production of rice groats. In order to remove dust, the group cyclone and the bag filter-cyclone are installed in the pneumatic conveying systems and suction plants of "Southern Rice Company", LLC. The paper shows the chemical composition of samples of husk, dust retained by the group cyclone, and dust retained by the bag filter-cyclone. Rice husk contains a significant amount of silicon dioxide $-14.8 \%$. The dust collected from the group cyclone contains ferrum (109 mg/kg), plumbum $(1.1 \pm 0.4 \mathrm{mg} / \mathrm{kg}$ ), and copper $(1.2 \pm 0.4 \mathrm{mg} / \mathrm{kg})$. The bag filter-cyclone retains finer dust particles. The dust collected in the cyclone is of yellowish-pink color, and the dust, collected from a bag filter-cyclone, is gray. Fine dust, which has passed through the filter, is drier than the dust, segregated in a cyclone, so it is more explosive and easily ignited. Dust can cause the explosion. The dust properties give an indication of the degree of its danger and the ability to form explosive concentrations in air.
\end{abstract}

Keywords: Rice husk, Rice dust, group cyclone, Bag filter-cyclone, Physical properties, chemical composition.

\section{INTRODUCTION}

Rice dust is formed during the processing of rice grain at a rice-processing plant as a result of the discharge upon the receipt of raw rice from vehicles, removal of impurities, sorting by size, during separation of membranes, crushing, grinding, polishing, moving grain along the elevators and conveyors, etc., i.e. during all technological operations of the rice groats production. 
High dust concentration in the air is one of the main adverse factors, resulting in environmental pollution and occupational diseases. Prolonged breathing in the dusty air causes heavy damage to human health. Dust with a diameter greater than 10 microns causes irritation of the upper respiratory tract.

Grain dust is a respiratory sensitizer. This means that it can cause an allergic reaction in the respiratory system. After this reaction takes place, a further effect on the material, even in very small amounts, causes symptoms. The following are the health impairment manifestations: rhinitis (runny nose or nasal congestion); cough and shortness of breath; asthma (coughing, wheezing, and chest tightness); chronic bronchitis (cough and sputum); chronic obstructive pulmonary disease (COPD) (long-term illness which makes breathing difficult and includes chronic bronchitis, chronic asthma); extrinsic allergic alveolitis (fever, cough, shortness of breath, joint pain, and weight loss). Organic dust is accompanied by a toxic syndrome, for example, grain fever (sudden onset of "influenza" with fever, often associated with cough and chest discomfort) ${ }^{1}$.

In order to determine the chemical composition of rice husk and dust, the authors selected the husk of the Regulus raw rice, which grows in the Krasnodar Region of the Russian Federation, and two dust grades, detained by a group cyclone and a bag filter-cyclone installed at the "Southern Rice Company", LLC (Kholmsk Station, Krasnodar Region, Russia).

\section{Related work}

It is shown in the paper [2] that the place of rice hulling (separation of fruit shells) is the most dangerous one. The dust content during hulling with the use of wooden mill is $22.44 \mathrm{mg} / \mathrm{cu}$.m., iron - 25 $\mathrm{mg} / \mathrm{cu} . \mathrm{m}$. All workers suffer lung diseases. Forced vital capacity (FVC) of all workers is less than $80 \%$, while the normal value shall be more than $80 \%$.

Waste in the form of fruit shells (husks, peeling, chaff) is significant. The volume of rice husk with hulling bran formed by rice grinding is $20-30 \%$ by grain weight. This annually renewable waste contains $28-30 \%$ of inorganic and $70-72 \%$ of organic compounds ${ }^{3}$. According to ${ }^{4}$, the composition of the organic compounds includes $\mathrm{C}, \mathrm{H}, \mathrm{O}, \mathrm{N}$ (Table 1). The inorganic components are represented mainly by silica. In general, the authors of ${ }^{3}$ proposed to consider rice husk as silica. The chemical composition of rice husk ash is given in Table 2.

Rice husk is used in agriculture and in various industries. Paper ${ }^{5}$ provides the concept of resource-saving processing of rice husk and straw, which provides pre-extraction of $\mathrm{SiO}_{2}$, followed by delignification of desilicated raw materials. For this purpose, straw and rice husk were treated with 1 $\mathrm{N}$ sodium hydroxide solution at $90^{\circ} \mathrm{C}$ for $60 \mathrm{~min}$. The proposed technology for oxidating-organosolv method of rice husk boiling allowed obtaining the high yield pulp $79.5 \pm 1.0$ from the rice husk. It was concluded that rice straw and husks are a promising raw material for the production of valuable products - silica and cellulose with a high product yield.

$\mathrm{In}^{6}$, the physical properties and chemical composition of the refractory clay and clay mixed with rice husk (Table 3) are studied.

The control sample showed a weak thermal resistance of one cycle, while the sample with the addition of husk has a thermal resistance of 10 cycles at $1200{ }^{\circ} \mathrm{C}$. The silica content is in the range $50-70 \%$. It is proposed to use such materials as the lining of thermal furnaces, melting furnaces, for point metals with low melting point. Elevated levels of iron oxide indicate the suitability of the material for the production of ceramics.

According to the results of laboratory tests, the grain dust surface area was determined to be 0.6-0.9 sq.m. $/ \mathrm{g}^{7}$, rice dust bulk density $-0.221 \mathrm{~g} /$ cu.cm, and the density of rice dust particles -1.46 $\mathrm{g} / \mathrm{cu} . \mathrm{cm}^{8}$.

The basic composition of the rice dust and the elemental composition of different portions of rice dust is presented in ${ }^{9}$ (Tables 4 and 5). It was noted that silica, cellulose and lignin are the main components of the rice dust. The paper presents the scheme of production of particle boards based on a mixture of rice dust with the resin followed by compression. To achieve high board quality, the husk is pulverized. 
Aspiration dust of grain processing industry is a set of residues of vegetable origin containing polysaccharides and other organic substances easily hydrolysable using $\operatorname{acid}^{10}$. The composition of aspirating waste of white, gray and black dust is provided in Table 6. The aspirating dust-based suspension hydrolysis was performed in the presence of a sulfuric acid with the concentration intervals from $1.0 \%$ to $8.0 \%$ at $100 \pm 0.1{ }^{\circ} \mathrm{C}$.

Fermentation was performed in the media derived from hydrolysates synthesized from the white, gray and black dust using acid solutions with the concentration of $1.0 \%$ to $5.0 \%$. Based on the analysis of the changes in the concentration of yeast during fermentation of different kinds of dust

Table 1: The composition of the rice husk organic compounds

\begin{tabular}{lccc}
\hline & \multicolumn{3}{c}{ Content, \% wt. } \\
C & H & O & N \\
\hline $39.8-41.1$ & $5.7-6.1$ & $0.5-0.6$ & $37.4-36.6$ \\
\hline
\end{tabular}

hydrolysates, it was established that grain processing businesses solid waste can be used as a source of digestible carbohydrates for yeast fermentation. Easily digestible carbohydrates are obtained by acid hydrolysis of aspiration dust polysaccharides ${ }^{10}$.

\section{METHODS}

In this work, the number of components was determined by the approved (RF) methodologies PND F 16.1: 2: 2.2: 2.3.46-06; PND F 16.1: 2: 2.2: 3.65-10; GOST 5180-2015.

The PND F 16.1: 2: 2.2: 2.3.46-06 methodology is based on inversely-voltammetric method, which is based on the dependence of the current passing through the analyzer cell with the test solution, on the mass fraction of the element contained in the solution and functionally linked to the form and parameters of the polarizing voltage applied to the electrodes. This method is based on the ability of the element of interest to electrochemically accumulate on the surface and dissolve in the anode or cathode polarization at a certain potential, which is characteristic for each

Table 2: The composition of the rice husk ash

\begin{tabular}{cccccccc}
\hline $\mathrm{SiO}_{2}$ & $\mathrm{Al}_{2} \mathrm{O}_{3}$ & $\mathrm{Fe}_{2} \mathbf{O}_{3}$ & $\mathrm{CaO}$ & $\mathbf{M g O}$ & $\mathbf{K}_{2} \mathbf{O}$ & $\mathrm{Na}_{2} \mathbf{O}$ & $\mathbf{P}_{2} \mathbf{O}_{5}$ \\
\hline 93.4 & 0.05 & 0.06 & 0.31 & 0.35 & 1.4 & 0.1 & 0.8 \\
\hline
\end{tabular}

Table 3: Physical properties and chemical composition of clay and clay with rice husk

\begin{tabular}{|c|c|c|c|c|c|}
\hline \multicolumn{6}{|c|}{ Physical properties } \\
\hline Sample & $\begin{array}{c}\text { Shrinkage } \\
\%\end{array}$ & $\begin{array}{c}\text { Apparent } \\
\text { porosity, \% }\end{array}$ & $\begin{array}{l}\text { Bulk density, } \\
\text { g/cu.cm }\end{array}$ & $\begin{array}{l}\text { Thermal } \\
\text { resistance, } \\
\text { cycles }\end{array}$ & $\begin{array}{c}\text { Fire } \\
\text { resistance, }{ }^{\circ} \mathrm{C}\end{array}$ \\
\hline Clay & 3.89 & 27.15 & 1.98 & 1 & 1,300 \\
\hline Clay mixed with husk & 3.00 & 36.74 & 1.52 & 10 & 1,200 \\
\hline \multicolumn{6}{|c|}{ Chemical composition } \\
\hline Sample & $\mathrm{SiO}_{2}, \%$ & $\mathrm{Al}_{2} \mathrm{O}_{3}, \%$ & $\mathrm{Fe}_{2} \mathrm{O}_{3}, \%$ & & \\
\hline Clay & 62.00 & 20.00 & 7.58 & & \\
\hline Clay mixed with husk & 54.70 & 12.00 & 7.99 & & \\
\hline
\end{tabular}


element. The peak height of the element recorded on voltammogram is proportional to the mass fraction of the element in the solution.

The method for the determination of silicon dioxide weight ratio (PND F 16.1: 2: 2.2: $3.65-10$ ) is based on the fusion of the sample with soda; smelt leaching and transfer of the metal salts in chlorides by treatment with hydrochloric acid; separating of silica using gelatin; ashing of silicic acid to silicon dioxide, and its determining using gravimetrical method.

The humidity of rice husk and dust (GOST 5180-2015) was determined by drying to constant weight. The dust samples were collected by quartering. Drying was carried out to obtaining a difference of dust (husk) masses with a weighing bottle during two subsequent weighings of not more than $0.02 \mathrm{~g}$.

\section{RESULTS}

"Southern Rice Company", LLC (S.R.C.) produces the gourmet brown rice of Regulus domestic variety, the qualitative characteristics of which exceed the similar parameters of the best imported samples. The technological stages of the raw rice production and the characteristics of aspiration systems like air pollutants were considered in $^{11-12}$.

The following two types of dust collectors (cyclones) are installed in the working house of "Southern Rice Company", LLC for cleaning of

Table 4: The elemental composition of different parts of the grain dust

\begin{tabular}{lccc}
\hline $\begin{array}{l}\text { Elemental } \\
\text { composition }\end{array}$ & $\begin{array}{c}\text { Outer surface of } \\
\text { husk, \% wt. }\end{array}$ & $\begin{array}{c}\text { Inside the } \\
\text { husk, \% wt. }\end{array}$ & $\begin{array}{c}\text { Inner surface } \\
\text { of husk, \% wt. }\end{array}$ \\
\hline C & 6.91 & 62.54 & 30.20 \\
O & 47.93 & 35.19 & 42.53 \\
Si & 45.16 & 2.27 & 27.27 \\
\hline
\end{tabular}

Table 5: The basic composition of grain dust

\begin{tabular}{lcccccc}
\hline Composition & $\mathrm{SiO}_{2}$ & Lignin & Cellulose & Protein & Fat & Other nutrients \\
\hline$\%$ wt. & $18.8-22.3$ & $9-20$ & $28-38$ & $1.9-3.0$ & $0.3-0.8$ & $9.3-9.5$ \\
\hline
\end{tabular}

Table 6: Composition of aspirating waste

\begin{tabular}{lccc}
\hline $\begin{array}{l}\text { Material } \\
\text { composition }\end{array}$ & \multicolumn{2}{c}{ Concentration of substances, \%, in various dusts } \\
White & Gray & Black \\
\hline Ash content & $5.46 \pm 0.07$ & $10.23 \pm 0.01$ & $23.34 \pm 0.07$ \\
Humidity & $5.46 \pm 0.07$ & $6.42 \pm 0.07$ & $14.04 \pm 0.07$ \\
Crude fat & $2.8 \pm 0.3$ & $1.3 \pm 0.3$ & $0.4 \pm 0.1$ \\
Protein & $7.4 \pm 0.1$ & $3.2 \pm 0.1$ & $1.2 \pm 0.1$ \\
Carbohydrates & & & \\
Easy hydrolysable & $32.0 \pm 0.1$ & $15.0 \pm 0.1$ & $13.1 \pm 0.1$ \\
Heavy hydrolysable & $40.0 \pm 0.5$ & $55.1 \pm 0.5$ & $36.1 \pm 0.6$ \\
Reducing agents & $0.4 \pm 0.1$ & $0.1 \pm 0.03$ & $0.1 \pm 0.03$ \\
Mineral mixture & $0.30 \pm 0.01$ & $5.00 \pm 0.01$ & $6.23 \pm 0.01$ \\
\hline
\end{tabular}


pollutant emissions. TSOL - for cleaning of dusty air coming from aspiration and pneumatic networks (sawdust, weeds, grain dust and other impurities) of particles larger than 126 microns, and U21-BBC-450 - the battery cyclone plant (Figure 1) with a $450 \mathrm{~mm}$ cyclone diameter. U21-BBC was made by category I of GOST 15150-69 (RF) in "U" climatic version (for the macroclimatic area with a temperate climate) releasing the purified air upward, and is designed to collect medium sized dust. The large grain dust collection efficiency is $95-98 \%$. The battery cyclone plant consists of four cyclones of conical-cylindrical shape. The cylindrical part of the cyclone includes inner and outer cylinders. The outer cylinder at the top is cut along the spiral line; a pipe is welded to it. The inner cylinder is inserted into the outer one. Four

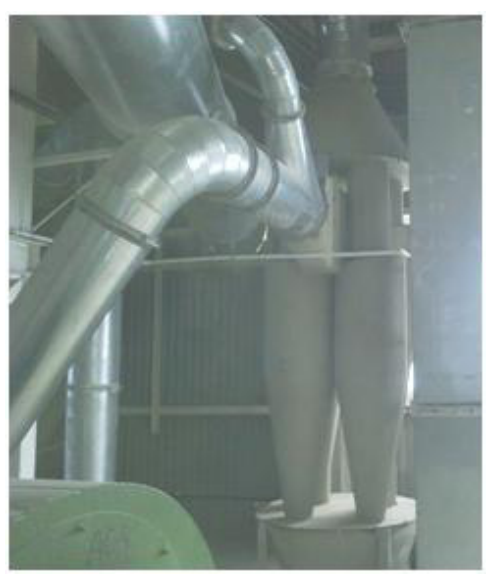

Fig. 1: AS-7 Group cyclone U21-BBC-450 of "Southern Rice Company", LLC cyclones are attached to the receiving hopper at the top. Dusty air is supplied in the cyclone through the inlet and its movement becomes a helical rotational one. By centrifugal force the dust particles press against the walls of the cyclone, lose speed and roll down into the collecting cone. With the help of the lock closures unit, the collected dust is discharged to the dust pipe, and through the exhaust pipes of cyclones and setup box purified air is discharged from the cyclones in the air duct. The air cleared of large and medium-sized particles enters the bag (B) filter-cyclone (C) BCIEU 24.0-37, which has a flat bottom and is provided with the impulse (I) blowing and electronic $(\mathrm{E})$ control unit $(\mathrm{U})$ with the filtration surface of 24 sq.m. and 37 bags. The dust is removed from the air during the air filtering through the fabric cross-linked as separate bags and embedded in a sealed filter case (Figure 2). The design of the bag filter represents a collapsible cabinet, divided into sections by vertical partitions. Each section has

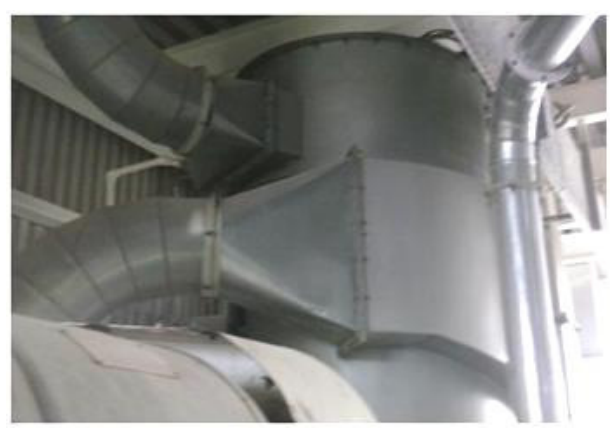

Fig. 2: Bag filter-cyclone BCIEU 24.0-37 of "Southern Rice Company", LLC

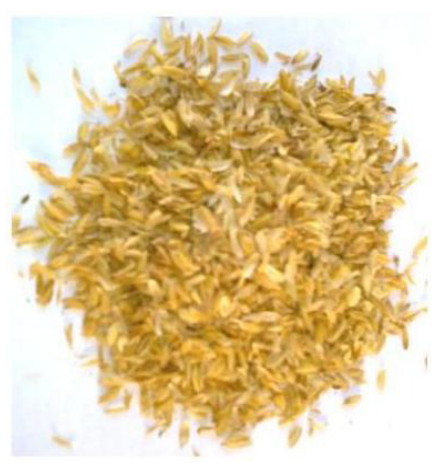

a) rice husk;

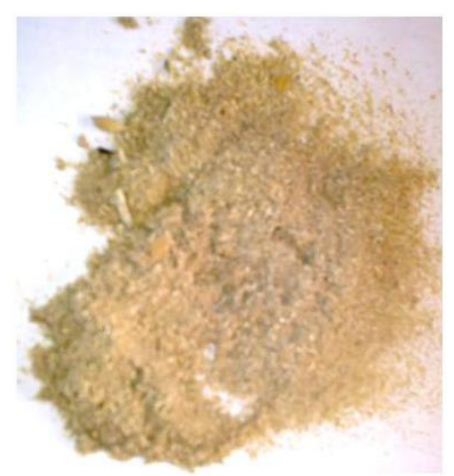

b) rice dust from the group cyclone;

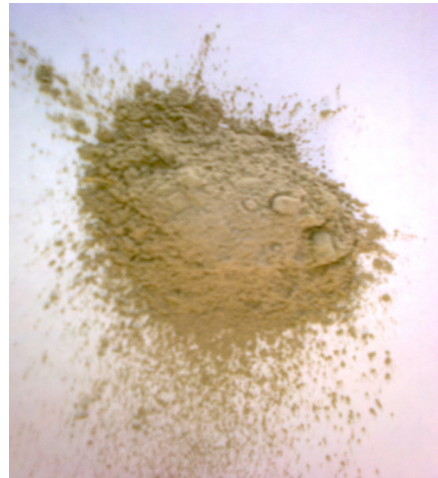

c) rice dust from the bag filter-cyclone

Fig. 3: Wastes from the raw rice production 
Table 7: Chemical composition of rice husk and dust, selected from group cyclone and bag filter-cyclone

\begin{tabular}{lccccc}
\hline $\begin{array}{l}\text { Determined } \\
\text { indicators }\end{array}$ & U.M. & \multicolumn{3}{c}{ Analysis result \pm error } & Measurement \\
& & $\begin{array}{c}\text { Rice } \\
\text { husk }\end{array}$ & $\begin{array}{c}\text { Dust from } \\
\text { group cyclone }\end{array}$ & $\begin{array}{c}\text { Dust from bag } \\
\text { filter-cyclone }\end{array}$ & \\
\hline Cadmium & $\mathrm{mg} / \mathrm{kg}$ & $<0.1$ & $<0.1$ & $<0.1$ & PND F 16.1:2:2.2:2.3.46-06 \\
Copper & $\mathrm{mg} / \mathrm{kg}$ & $1.8 \pm 0.5$ & $1.2 \pm 0.4$ & $<1.0$ & \\
Mercury & $\mathrm{mg} / \mathrm{kg}$ & $<0.1$ & $<0.1$ & $<0.1$ & \\
Nickel & $\mathrm{mg} / \mathrm{kg}$ & $<0.5$ & $<0.5$ & $<0.5$ & \\
Plumbum & $\mathrm{mg} / \mathrm{kg}$ & $2.4 \pm 0.6$ & $1.1 \pm 0.4$ & $<0.5$ & \\
Zink & $\mathrm{mg} / \mathrm{kg}$ & $1.2 \pm 0.4$ & $<1.0$ & $<1.0$ & \\
Cobalt & $\mathrm{mg} / \mathrm{kg}$ & $<0.5$ & $<0.5$ & $<0.5$ & \\
Ferrum & $\mathrm{mg} / \mathrm{kg}$ & 126 & 109 & $<100$ & \\
Manganese & $\mathrm{mg} / \mathrm{kg}$ & $<10$ & $<10$ & $<10$ & \\
Arsenic & $\mathrm{mg} / \mathrm{kg}$ & $<0.1$ & $<0.1$ & $<0.1$ & \\
Selenium & $\mathrm{mg} / \mathrm{kg}$ & $<0.1$ & $<0.1$ & $<0.1$ & \\
Antimony & $\mathrm{mg} / \mathrm{kg}$ & $<1.0$ & $<1.0$ & $<1.0$ & \\
Bismuth & $\mathrm{mg} / \mathrm{kg}$ & $<1.0$ & $<1.0$ & $<1.0$ & \\
Silicon dioxide & $\%$ & 14.8 & $<5$ & $<5$ & PND F 16.1:2:2.2:3.65-10 \\
Humidity & $\%$ & 6.7 & 4.5 & 2.9 & GOST 5180-2015 \\
\hline
\end{tabular}

the cylindrically-shaped filter bags. The bags are stretched on a metal frame. The bags are periodically cleaned of dust deposited thereon as a result of their shaking through a special mechanism.

To determine the chemical composition of the waste generated during the processing of raw rice, the samples of husk, dust, detained by the group cyclone and dust, detained by a bag filter-cyclone, were selected (Figure 3).

The chemical composition of the rice dust and the husk is shown in Table 7. The rice husk contains a significant amount of silicon dioxide $14.8 \%$. The dust collected from the group cyclone contains ferrum ( $109 \mathrm{mg} / \mathrm{kg})$, plumbum $(1.1 \pm 0.4 \mathrm{mg} /$ $\mathrm{kg})$, and copper $(1.2 \pm 0.4 \mathrm{mg} / \mathrm{kg})$. Due to abrasive particles, ferrum is removed from gravity flow during grain movement; the fraction becomes heavy and is deposited in the cyclone under the centrifugal force. Wetter particles stick together and become larger. Man-made emissions of heavy metals, which include ferrum, plumbum and copper, cause global pollution as a result of man-made dispersion. Upon flushing of rice dust in stagnant basins, heavy metals increase its acidity and contribute to the intensification of $\mathrm{CO}_{2}$ as a result of the microorganisms activity. Bag filter-cyclone detains smaller dust particles, which is consistent with the dust samples, listed in Figure 3.

\section{DISCUSSION}

Thus, the chemical composition analysis (Table 7) shows that the rice husk is mainly characterized by the presence of silicon dioxide, coinciding with the opinion of the authors of [3]. It should be noted that the dust color changes from more light, yellowish-pink (Figure $3 b$ ) to dark gray (Figure 3c). This can be explained by the fact that pure copper gives to the dust the gold-pink color, but under the influence of different media the color changes and becomes brown-red. The presence of ferrum gives the dust particles a silver-white color, and the ferrous oxides - the red one. The zinc dust is light gray, but the color fades when exposed to air. As it was mentioned above, the heavier dust particles containing iron are deposited in the battery cyclone plant. 


\section{CONCLUSION}

The dust properties give an indication of the degree of its danger and the ability to form the explosive concentrations in air. Dust can be a cause of the explosion, which is able to blow out the concrete walls of the silo, to carry away the concrete superstructures over a distance of a few blocks, to raise the grain silos weighting hundreds of tons. Fine dust, which has passed through the filter is drier than the dust, segregated in a cyclone, so it is more explosive and easily ignited ${ }^{13}$. In the Russian Federation, the grain dust refers to the 2nd hazard class by explosiveness and flammability (explosive dusts with the LEL (lower explosive limit) with a concentration from 16 to $65 \mathrm{~g} / \mathrm{cu} . \mathrm{m}$.).

\section{REFERENCES}

1. Health and Safety Executive. Grain Dust. Guidance Note (3rd ed.). HSE Books. 2013. Available at: http://www.hse.gov.uk/pubns/ eh66.pdf.

2. Batsungneon, K.; Kulworawanichpong, T. Effect of Dust Particles in Local Rice Mills on Human Respiratory System. World Academy of Science, Engineering and Technology, 2011, 80, 421-426.

3. Sergienko, V.I.; Zemnukhova, L.A.; Egorov, A.G.; Shkorina, E.D.; Vasilyuk, N.S. Vozobnovlyaemye istochniki khimicheskogo syr'ya: kompleksnaya pererabotka otkhodov proizvodstva risa i grechikhi [Renewable Sources of Chemical Raw Materials: Complex Processing of Rice and Buckwheat Production Waste]. Russian Chemical Society Journal of them. DI. Mendeleev, 2004, XLVIII(3), 116124.

4. Koz'mina, E.P. (Ed.). Ris i ego kachestvo [Rice and Its Quality]. Moscow: Kolos, 1976.

5. Vurasko, A.V.; Driker, B.N.; Mozyreva, E.A.; Zemnukhova, L.A.; Galimova, A.R.; Gulemina, N.N. Resursosberegayushchaya tekhnologiya polucheniya tsellyuloznykh materialov pri pererabotke otkhodov sel'skokhozyaystvennykh kul'tur [ResourceSaving Technology for Producing Cellulosic Materials during Crops Waste Processing] Khimiya rastitel'nogo syr'ya, 2006, 4, 5-10.

6. Hassan, M.A.;Yami, A.M.; Raji, A.; Ngala, M.J. Effects of Sawdust and Rice Husk Additives on Properties of Local Refractory Clay. The International Journal of Engineering and Science, 2014, 3(8), 40-44.

7. Wade, F.J.; Hawk, A.L.; Watson, C.A. A Survey of Grain Dust Properties at Large Grain Terminal. In: Proceedings of the International Symposium of Grain Dust. Manhattan, KS: Kansas State University, 1979.
8. Parnell, C.B.; Jones, D.D.; Therford. R.D.; Goforth, K.J. Physical Properties of Five Grain Dust Types. Environmental Health Perspectives, 1986, 66, 183-188.

9. Johnson, A.C.; Yunus, N. Particleboards from Rice Husk: A Brief Introduction to Renewable Materials of Construction. Jurutera, 2009, 6, 12-15.

10. Karpova, G.V.; Zainutdinov, R.R. Aspiratsionnaya pyl' zernopererabatyvayu shchikh predpriyatiy kak istochnik legkousvaivaemykh uglevodov dlya fermentatsii drozhzhey [Aspiration Dust of Grain Processing Enterprises as a Source of Digestible Carbohydrates for Yeast Fermentation]. Bulletin Orenburskogo State University, 2002, 3, 9599.

11. Donenko, A.P., Korotkova, T.G., \& Melekhina, O.V. Povyshenie urovnya ekologicheskoy bezopasnosti protsessa ochistki risa-syrtsa ot primesey na $\mathrm{OOO}$ "Yuzhnaya risovaya kompaniya" [Increasing the Level of ecological Safety of Raw Rice Cleaning Process from Impurities at the "Southern Rice Company", LLC]. Proceedings of the universities. Food technology, 2015, 2-3, 93-96.

12. Donenko, A.P., Korotkova, T.G., Melekhina, O.V., \& Pashinyan, L.A. Tekhnologicheskie stadii protsessa pererabotki risa-syrtsa na $\mathrm{OOO}$ "Yuzhnaya risovaya kompaniya" [Technological Stages of the Raw Rice Processing at the "Southern Rice Company", LLC]. Scientific works KubGTU, 2015, 4, 338-347. Available at: http://ntk.kubstu.ru/ file/395.

13. Ostorozhno - zernovaya pyl [Caution! Grain dust]. Moscow: NPF "Skarabey", LLC. Retrieved, N. D. Available at: http:// www.fumigaciya.ru/sites/default/files/public/ page/2013-01/315/ostorozhnozernovayapyl. pdf. 